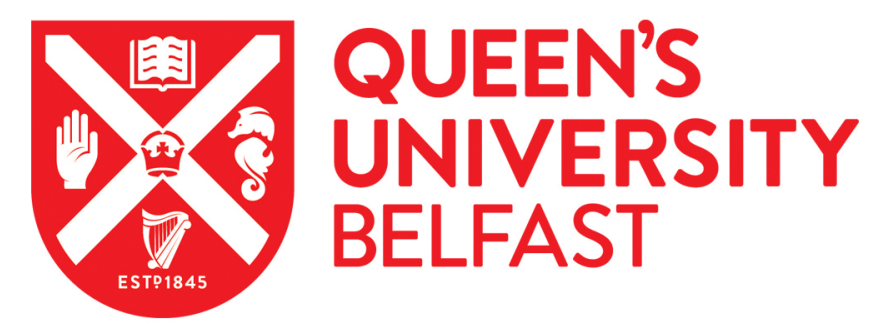

\title{
Surviving Cell-Sharing: Resistance, Cooperation and Collaboration
}

Muirhead, A., Butler, M., \& Davidson, G. (2023). Surviving Cell-Sharing: Resistance, Cooperation and Collaboration. Punishment and Society, 25(2), 500-518. https://doi.org/10.1177/14624745211062869

\author{
Published in: \\ Punishment and Society
}

Document Version:

Publisher's PDF, also known as Version of record

Queen's University Belfast - Research Portal:

Link to publication record in Queen's University Belfast Research Portal

Publisher rights

(C) 2021 The Authors.

This is an open access article published under a Creative Commons Attribution License (https://creativecommons.org/licenses/by/4.0/), which permits unrestricted use, distribution and reproduction in any medium, provided the author and source are cited.

\section{General rights}

Copyright for the publications made accessible via the Queen's University Belfast Research Portal is retained by the author(s) and / or other copyright owners and it is a condition of accessing these publications that users recognise and abide by the legal requirements associated with these rights.

Take down policy

The Research Portal is Queen's institutional repository that provides access to Queen's research output. Every effort has been made to ensure that content in the Research Portal does not infringe any person's rights, or applicable UK laws. If you discover content in the Research Portal that you believe breaches copyright or violates any law, please contact openaccess@qub.ac.uk. 


\section{Surviving cell-sharing: Resistance, cooperation and collaboration}

\section{Aimee Muirhead (D), Michelle Butler (D), and Gavin Davidson}

School of Social Sciences, Education and Social Work, Queen's University Belfast, UK

\begin{abstract}
For decades, researchers have sought to understand the impact of imprisonment; yet we have a limited understanding of the lived experience of cell-sharing. To address this gap in knowledge, this paper draws on 37 semi-structured interviews with imprisoned adult men in Northern Ireland. While demonstrating that, for most, cell-sharing was a negative experience, imbued with discomfort, unease and distress, a new conceptual framework is presented that seeks to understand the tactics people use to manage cellsharing, influences on their choice of tactics and the potential repercussions of these tactics. Potential implications for policy and practice are also discussed.
\end{abstract}

\title{
Keywords
}

cellmates, prison cells, adaptation, overcrowding

Cell-sharing is a unique experience, as strangers are often forced to share a small space against their will. Yet, cell-sharing is far from a unique event. Internationally, cell-sharing takes many forms, and there are concerns that cell-sharing causes distress, discomfort and impingements upon privacy, safety and dignity (Community Justice Coalition, 2018; European Parliament, 2017). There are particular fears that cell-sharing can increase violence, distress and ill health, hindering efforts to reduce crime and promote rehabilitation

\section{Corresponding author:}

Michelle Butler, School of Social Sciences, Education and Social Work, Queen's University Belfast, 6 College Park, Belfast, BT7 INN, UK.

Email: michelle.butler@qub.ac.uk 
and desistance (Grant and Memmott, 2007). However, little is known about the lived realities of cell-sharing and how cellmates manage this aspect of their imprisonment (Molleman and van Ginneken, 2015). This is a significant blind spot, given the cell is the space where people spend most of their time in prison. This paper addresses this gap by qualitatively exploring the lived realities of cell-sharing and the tactics used to manage the shared cell space and cellmate relationships. In doing so, it makes a threefold original contribution to knowledge. First, it illuminates how cell-sharing is experienced by men and may affect their experience of imprisonment. Secondly, it outlines the different tactics people use when faced with cell-sharing and conceptualises these tactics as existing on a continuum of resistance, cooperation and collaboration. Thirdly, as no previous work has examined how people manage cellmate relationships, this conceptualisation offers a new framework to help understand where on this continuum people's tactics to manage cell-sharing and cellmate relationships may fall, as well as identifying how people's positioning on this continuum may change.

\section{The pains of imprisonment}

Imprisonment can cause considerable physical and psychological harm (Clemmer, 1958; Irwin and Owen, 2005; Toch, 1977). Sykes (1958) conceptualised imprisonment as causing five 'pains', involving the deprivation of liberty, goods and services, heterosexual relationships, autonomy and security. Prison regimes in the 21 st century cast a different hue on these pains (Crewe, 2011). For instance, Crewe (2011) notes the additional 'pain of self-government', whereby individuals face not only a deprivation of autonomy but increased scrutiny regarding the range of actions over which they are permitted to exercise choice. More recently, Haggerty and Bucerius (2020) highlight new forms of pains, such as gendered pains, pains beyond prison walls and more modern pains specific to contemporary imprisonment, yet also caution against the overuse of the term 'pain'. Despite the wealth of literature investigating the pains of imprisonment, cell-sharing has often been omitted from considerations of how imprisonment can be painful. This paper does not argue that cell-sharing itself constitutes a new pain of imprisonment but rather that the shared cell is a space where some pains (particularly the deprivation of autonomy, liberty and safety) are most acutely experienced.

Shared cells are often used as a means for prisons to absorb population pressures when faced with overcrowding. Overcrowding exacerbates the pains of imprisonment in several ways, having been linked to tense prison social climates, higher levels of assault, bullying and increased rates of suicide and self-harm (Haney, 2012; Huey and McNulty, 2005; Lawrence and Andrews, 2004; Marshall et al., 2000). When two individuals share a cell, there is the potential for violence, bullying and physical or sexual assault to occur (de Viggiani, 2007; Grant and Memmott, 2007; Keith, 2006). Furthermore, overcrowding limits opportunities for constructive activity, such as education, training and mental health support, due to the strain on already limited resources (CJINI, 2012; Prison Reform Trust, 2018). Many organisations and researchers criticise the use of shared cells due to their potential negative impact (Community Justice Coalition, 2018; European Parliament, 2017; Grant, 2020; Grant and Memmott, 2007; 
Shook, 2013; Schliele and Crewe, 2021) but, nevertheless, prison overcrowding remains a chronic issue in many jurisdictions. For example, in $2020,35 \%$ of the prison population in England and Wales were sharing cells with two or more people, with some spending over 22 hours a day in a shared cell (HMIP, 2020). Indeed, avoiding a shared cell has been reported as one reason individuals may seek to be held in segregation (Shalev and Edgar, 2015).

The complexity of prison spaces and their influence on behaviour, social interactions and the perception of the pressure exerted by masculine social norms has been recognised in the literature (Butler et al., 2015, Crewe et al., 2014; Laws and Crewe, 2016; Moran et al., 2013; Turner and Knight, 2020). Male prison social norms based on traditional masculine ideology form a backdrop for interactions in prison spaces. Whilst single cells may provide a degree of reprieve from such pressures, cellmates may not be immune to feeling that their behaviour should reflect widely (though not universally) held values like strength, power, the suppression of emotion and the rigid policing of relationships with other men (Evans and Wallace, 2008). In overcrowded dormitory cells shared by up to 200 people in the Philippines, Narag and Jones (2020) highlight how the wider social context and normative values shape experiences of cell-sharing, adherence to which sustains a sense of order and governs cell-life. Nonetheless, navigating these social norms in a shared cell may be challenging, as Woolf's (2020) examination of physical cell features builds a picture of a site bounded in emotional pain.

Hyatt et al. (2020) explore how the architecture of the cell-space reflects a jurisdiction's underlying penal philosophy, with cell design either promoting or restricting levels of privacy and impacting not only the experience of imprisonment but also desistance efforts. Some propose that focusing on the 'micro-scale' (Woolf, 2020: 114) of the cell, in conjunction with the sensory impact and individuals' choices on how to interact with the space, can build a better understanding of the lived realities of cell-sharing (Herrity, 2020; Marti, 2020). Nevertheless, few studies have examined the individual experience of cell-sharing, focusing instead on systemic issues relating to overcrowding (Lawrence and Andrews, 2004). Yet, some argue that cell-sharing and overcrowding cannot be treated interchangeably (Molleman and van Ginneken, 2015). The studies that do examine the individual experience of cell-sharing often touch on it as an issue tangential to other research questions (Laws and Crewe, 2016; Schliehe and Crewe, 2021; van Harreveld et al., 2007). Only recently have studies started to focus on the prison cell itself and how people experience cell-sharing (Grant and Memmott, 2007; Muirhead, 2019; Muirhead et al., 2020; Muirhead et al., 2021; Schliehe and Crewe, 2021; Turner and Knight, 2020).

While more attention is being devoted to the prison cell as a space, understanding what happens when individuals must share that space has not been fully explored. Schliehe and Crewe (2021) highlight how cell-sharing reaches into the most personal parts of people's lives, affecting feelings of sensory intrusion, safety, dignity and abjection. Nonetheless, Schliehe and Crewe (2021) note that people can form cellmate relationships characterised by humanity, kindness and care that help to make their situation more survivable. Muirhead et al. (2021) found that good cellmate relationships could enhance wellbeing beyond that experienced in a single cell, due to the potential for cellmates to provide 
Punishment \& Society $0(0)$

mutual positive social and emotional support. However, Muirhead et al. (2021) also found that poor cellmate relationships could worsen wellbeing beyond that experienced in a single cell, due to the strain individuals experience attempting to conceal their emotions and vulnerabilities, as well as fears for their safety. Nonetheless, due to the paucity of research, little is known about how people in shared cells manage cellmate relationships. This paper addresses this gap by qualitatively exploring how the lived realities of cell-sharing are experienced by adult males and, additionally, the tactics they use to manage the shared cell space and cellmate relationships.

\section{Methods}

To explore the lived experiences of cell-sharing, in-depth semi-structured interviews were conducted with adult men detained in the Northern Ireland Prison Service (NIPS). The interviews formed part of a larger, mixed method study, including a random stratified survey of imprisoned adult males and semi-structured interviews with staff, exploring issues relating to cell-sharing and wellbeing. Findings from the survey and staff interviews are not presented here, as this paper focuses on the lived experience of cell-sharing and wishes to amplify the voices of those who experienced cell-sharing. For more information on the survey findings and semi-structured interviews with staff, please see Muirhead (2019), Muirhead et al. (2020), as well as Muirhead et al. (2021).

Thirty-seven imprisoned adult men were interviewed about their experiences of cellsharing from across the two prisons that housed adult men in Northern Ireland (NI): Maghaberry and Magilligan prisons ${ }^{1}$. These men were purposively chosen from those who expressed an interest in participating in an interview while completing the random stratified survey, in which the mean age was 36 years old, with a range of 21 to 77. Interviewees were purposively chosen based on having previous experience of being detained in a shared cell, willingness to give informed voluntary consent, ability to understand English, not deemed to pose a risk of violence to the researcher and not experiencing acute incidents of physical or mental ill health during data collection.

Ethical approval was obtained from Queen's University Belfast (QUB) and NIPS. Interviewees were fully informed about the research before voluntarily consenting to participate. Interviews were conducted in a private room on prison landings and recorded with the permission of interviewees and NIPS. Limited confidentiality and anonymity were offered, with interviewees being aware of the limits to confidentiality and anonymity before consenting to participate. Serious crime, harm to self or others or attempts to escape were required to be reported to a relevant authority, and anonymity and confidentiality could not be guaranteed in these circumstances. The semi-structured interview was based on an interview schedule developed in advance, informed by relevant topics identified through a literature review that covered cell-sharing experiences, cellmate relationships, managing the shared cell space and potential effect of cell-sharing on wellbeing/ experience of imprisonment. The data was stored securely at QUB and only accessed by the research team and transcriber (who signed a confidentiality agreement). 
Anonymised interview transcripts were uploaded to NVivo and analysed following Braun and Clarkes (2006) six stages of thematic analysis: data familiarisation, coding, searching for themes, reviewing themes, defining and naming themes, and writing up. The researchers remained reflexive throughout the process, recording reflections in a research journal during data collection and analysis, and were mindful of how the interviewer's position as a young woman appeared to have made interviewees feel comfortable sharing personal experiences. Overall, a data-driven, inductive approach to coding was undertaken, which was best suited to answering the research questions, given the lack of research on this topic.

\section{Findings}

\section{The lived experience of cell-sharing}

Most (though not all) interviewees explained a preference for a single cell based on a feeling of disempowerment and a lack of control when they were assigned a cellmate, who was potentially a stranger. This lack of agency was juxtaposed with the magnitude of the adaptations that sharing a cell required cellmates to make:

Imagine if somebody just came and went, here, I am moving somebody into your bedroom. And see all your stuff, move it all to the side because they've to have half of your space and all [...] somebody you don't know, somebody you don't trust and somebody that you probably don't like. Know what I mean? It is not nice. It is not natural. (P05)

Being faced with cell-sharing brought about different feelings and emotions. Many encountered wariness about their prospective cellmate, especially if they did not know the person:

It was something I experienced with the other fella, you know the first night, just wary. Is he asleep? Or am I going to wake up and he is robbing me or something, like. (P03)

For some, this wariness was felt more acutely, spilling over into a fear for their personal safety. While not knowing their cellmate fuelled such fears, interviewees were also concerned about potential volatile or violent behaviour due to a cellmate's mental ill health or drug misuse.

You had to be on edge, because you don't know what way he is going to react, especially doing drugs all day every day, you know. You don't know what mood he is going to be in if he doesn't have them. So it can be a wee bit disturbing, like. (P26)

There's always that thing in the back of your head that I might not wake up the next day if he was to snap. Or I might wake up beside somebody dead if he done something to himself. So that was always in the back of my mind. (P28) 
Some individuals who had previous experiences of trauma or because of aspects of their identity, such as their sexuality or race, were particularly conscious of potentially being at risk from their cellmate:

I was talking to him and I just put it out there straight away. I was like, listen mate, I am gay. You are not going to have a problem with this, are you? And he said no. I don't care. (P02)

[Cellmate] would come into my space. I got abused when I was a child [...] and I told him about this. I says look, you are making me feel awkward here. And I told him, enough is enough. But he still does it. (P16)

Such fears lead men to 'sleep with one eye open' (P19), showing how a cellmate could cause a cell to morph from a space once experienced as 'a sanctuary' (P11) to a terrain where it was difficult to let one's guard down. Instead, interviewees reported 'tip-toeing around on eggshells because they [cellmate] are unpredictable' (P32).

This hypervigilance was perhaps exacerbated by the close proximity of one's cellmate. At the time of data collection, the dimensions of a shared cell in Northern Ireland tended to be between 6.8 and $7 \mathrm{~m}^{2}$ (Silvestri, 2013). The men described difficulty moving around a shared cell and performing basic tasks, like washing, dressing and watching television, without 'squeezing past each other' (P21). There were repeated references to coming into physical contact with a cellmate when moving in the cell:

You are so close to that other person. You are almost sitting on their knee (P04)

Two people can't stand up in the cell at the same time because you can't move. (P18)

For some, the inherent closeness of a cellmate was experienced as stress-inducing and claustrophobic:

It makes my skin crawl or something. It just makes me so stressed. [...] You are too close to me. (P05)

Extreme physical proximity to a cellmate whom an individual was wary or even fearful of could make the experience of cell-sharing more difficult. There was a very real sense of inescapability, not merely in relation to the physical space but from the perceived threat that a cellmate could pose, as a result of such small dimensions.

Distress could also be amplified by physical proximity. Interviewees spoke of how cellmates' toilet usage, personal hygiene and bodily functions were inescapable, with their senses being assaulted by the sights, smells and sounds associated with such activities.

You are lying at the bottom of your bed and you are in the fucking toilet, basically, and piss hitting you in the face (P33) 
And then you've to sit and listen to them farting all night and getting up and going to the toilet. (P16)

I could smell him from the bottom bunk (P14)

Such exposure was experienced as 'extremely degrading' (P2) and regarded as excessively punitive by some, resulting in a sense of personal degradation and contamination that made a shared cell appear much less desirable than a single cell.

The deficit in privacy in a shared cell further meant that individuals struggled with using the toilet, washing and dressing in front of their cellmate.

It was hard for me. I didn't go to the toilet, I think, for about the first four or five days when I was in here. (P28)

Worries also extended to concerns about cellmates interfering with/stealing private possessions, with many men reporting being deeply uncomfortable leaving an unknown cellmate alone in a shared cell:

People worry that if you go on a visit or you go out to the exercise yard, the guy you are sharing a cell with, what's he doing in the cell? Is he going through your locker and looking at your private mail? Is he going through paperwork? (P16)

Moreover, individuals reported being exposed to potential stigma as a result of who they shared a cell with, explaining that their cellmate's offences could affect their status and social interactions with others. For example, most men were staunchly opposed to sharing a cell with a sex-offender or a 'tout' ${ }^{2}$, as associating with such a cellmate was viewed as having a toxic impact on their reputation, even if the cell allocation was involuntary.

You'd be labelled as a tout if you are talking to them. And you'd get into loads of trouble and just it will fuck your mental health up. (P27)

They spoke of experiencing social stigma if they were perceived to be sharing amicably with such a cellmate and described an expectation that they would assault a cellmate who was a sex offender/'tout' or risk being ostracised.

People would be expecting you to react to that. [...] That you would react and there would be violence, you know [Interviewer: What would happen if you didn't react?] I don't think many people would be too happy with you. (P18)

For a minority of interviewees, however, cell-sharing represented a more positive experience, offering the opportunity for company and distraction from boredom: 
As long as you get along with who you are doubled up with, [cell-sharing] can be a lot better, because you have someone to talk to. You are not sitting thinking or in your own head [...] You are talking, you are maybe playing the computer or the Xbox. (P34)

However, as the interviewee above points out, this was strongly dependent on who the cellmate was. A cellmate's offence, their personality and behaviours influenced whether a positive relationship formed, which could range from supportive friendships to more rare, intimate, sexual relationships:

We've got a bromance! And like it is genuine care and support we are giving each other. (P36)

One of the things to consider... is there a potential for, do you know, a sexual relationship with someone when you are doubled up in a cell. And that can be extremely scary and intimidating. But, in some instances, it does actually happen and can be extremely gratifying and stuff. (P02)

Yet, such positive relationships were not often encountered. Instead, the norm was for cellmates to acquiesce to the inevitability of cell-sharing, bearing it with grudging acceptance:

When you are in prison you sort of have to [...] sort of expect things like that. You know, nobody really likes getting moved and all the change and all that, but you have to expect these things. (P26)

Nevertheless, not everyone chose to accept cell-sharing. Some resisted their allocation to a shared cell by making threats, wrecking the cell, taking their cellmate hostage or acting violently towards cellmates or staff:

So, when they [staff] tried to put me in with him [cellmate], I just went to him and I says, listen [...] if you are not out by the time I come back, I am going to slice your throat. (P07)

Resisting placement in a shared cell in this way was an opportunity for individuals to enact expressions of masculine prison social norms, displaying power and strength.

Consequently, many experienced feelings of wariness, fear and discomfort, often mixed with a grudging acceptance of cell-sharing, though a small number sought to resist it. In contrast, a minority believed cell-sharing could provide relief from boredom and isolation. These different feelings and experiences could influence how willing individuals were to work with their cellmate and the tactics they used to manage cell-sharing. While this may seem self-evident, few have examined how these feelings and experiences shape the tactics employed to manage the shared cell space or cellmate relationships. 


\section{Cell-sharing tactics: A continuum}

Based on the men's accounts, people's willingness to work together to minimise the pains associated with cell-sharing could be conceptualised as existing on a continuum ranging from resistance to cooperation to collaboration (see Figure 1). People's positioning on this continuum influenced the tactics used to manage cell-sharing. Figure 1 shows the continuum and how cell management tactics differed, depending on where on the continuum they fall. It is important to note that these tactics are not necessarily mutually exclusive, as tactics can overlap. Moreover, an individual's choice of tactic is not fixed, as cellmates' willingness to work together may change. For instance, while some individuals may start at a certain point on the continuum, they may change their outlook, depending on events within the cell and their cellmate's characteristics. The complexity of the potential combinations and variations in responses to cell-sharing
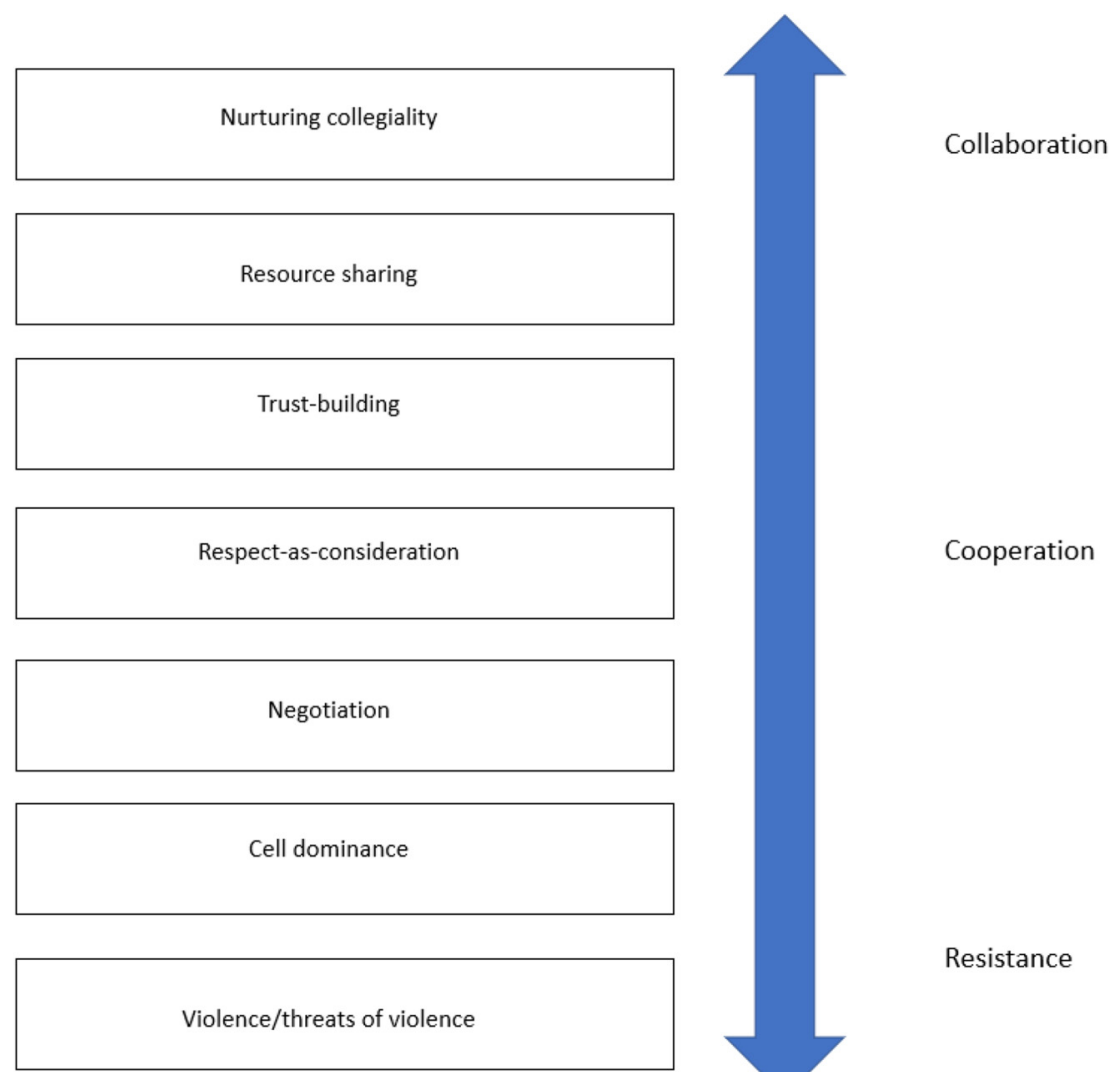

Cooperation

Resistance

Figure I. A continuum of cell-sharing and cell-sharing tactics. 
means that the continuum is not a definitive, linear model but, rather, a helpful illustration of the range of tactics used.

Beginning at the resistance end of the continuum, people were unwilling to cell-share either because they were completely resistant to cell-sharing or they disapproved of the shared cell conditions or cellmate's characteristics. Where men were resistant to cell-sharing, they tended to use violence and/or threats of violence as a tactic to avoid cell-sharing.

I would just point-blank refuse. I'd sooner go to the Block. [...] It's better getting a single cell over there than sharing with some head case over here. (P25)

Moving up the continuum, some people were willing to cell-share provided they could 'rule the roost' (P01). Such individuals chose to dominate the shared cell space rather than cooperate or collaborate with their cellmate and drew on established masculine prison social norms of strength and assertiveness to establish themselves as the dominant presence within the cell.

If he comes in and he thinks he is going to take over, we will have a problem. (P01)

Yet, such a tactic could lead to violence, bullying and harassment.

I wouldn't have a cellmate who talks. Are you joking? Simple... simple. I would just open the door one day and he'd be lying on the floor. I would say he fell. Pick him up, take him away, he fell (P17)

The men recounted how cellmates could often be the source of experiences of bullying, harassment and violence.

If you are getting your meds, you have more chance [of being bullied] with somebody in the cell... I'll have those, thank you. Say anything and you are getting it. (P07)

Such situations were very difficult to deal with and distressing, as interviewees explained that people tended not to report such incidents to staff for fear of being labelled a 'tout' and the social/physical consequences that would follow.

How could they go and report them? They can't walk up to that desk in that office and say, the guy in cell five is bullying me. Because the guy in cell five is standing beside him. (P13)

More commonly, interviewees stated that people reluctantly acquiesced to the cellsharing arrangement if prospective cellmates were not thought to be sex offenders or 'touts'. The men explained that they accepted that cell-sharing was a feature of prison life, which they often had little control over, and sought to cooperate with their cellmate to negotiate their actions in the shared cell to make the situation tolerable.

You have to pull your weight. Both of you. (P11) 
Actions in the cell and interactions with cellmates were based on a 'give and take' (P37) attitude. With an air of grim resignation, they simply got on with making the situation as manageable as possible.

You are not going to get out of it until the door opens. So you sort of have to get on with each other. (P37)

There was an implicit acknowledgment that neither wanted to be in this situation, but they sought to cooperate with each other to minimise the pains of cell-sharing. In some cases, the men described automatically adapting their behaviour to take account of the presence of a cellmate, while, in other instances, the management of space was actively negotiated to lessen the loss of privacy, intrusion on personal space, lack of safety and stress associated with cell-sharing.

Sometimes people would discuss it; like I'm going to the toilet here, do you want to leave the cell for a minute or do you want to stick your head out the window. Because you don't want to be staring at someone when he's going to the toilet. (P28)

In this way, cellmates could negotiate agreed ground rules to manage their shared cell space and interpersonal interactions in such a way that met their needs, while minimising the risk of conflict, loss of privacy and decreased friction.

I help out [cleaning the cell]. So you have to do that. You have to share that equally. That can cause problems, you know. Some guys will take the piss on that. But if he is doing his fair share and I am doing my fair share, it is a happy house. (P36)

The successful negotiation of the shared cell space could facilitate the development of mutually respectful relationships. This could move the extent to which individuals were willing to work together from simply doing the minimum required to minimise the pains of cell-sharing to people being motivated to adjust their behaviours out of a sense of respect for their cellmate and their needs. This demonstrated a form of respect-as-consideration (Butler and Drake, 2007), whereby cellmates viewed each other as entitled to a basic level of courteous treatment and adjusted their actions accordingly. For instance, the men highlighted how they adjusted their actions to avoid waking a sleeping cellmate or looking at their cellmate when they were using the toilet.

Because if you get up, you've to sort of tip-toe about [...] and be a wee bit courteous. Be a wee bit quiet. And you don't want to slap about the cell in case you wake him up (P25)

Respect-as-consideration was also demonstrated by enabling one's cellmate to have their own space in the shared cell. Interviewees spoke of needing to have their 'own space to think' (P32) and their bed as 'the only space you have' (P32) in a shared cell. It was explained that people needed their own space to reflect on their memories, work through their issues and process their thoughts and emotions. 
Everybody has all these issues going on. And I think everybody needs somewhere where they can just go and sit and think and be quiet. (P06)

Cooperating cellmates acknowledged that, for each of them, cell-sharing could bar access to such a space and were willing to grant each other what amount of peace and quiet they could, out of respect for each other.

Nevertheless, men spoke about needing to strike a 'balance' (P35) between being respectful and standing up for oneself in a manner that adhered to masculine prison social norms regarding strength and assertiveness:

But you have to be able to be strong enough to turn round and stand up, like I said to my cellmate this morning. Not happening. (P16)

Therefore, individuals had to ensure that their displays of respect-as-consideration did not veer into appeasement that would create a reputation of spinelessness or being weak-willed.

Some interviewees stated that they were open to collaborating with their cellmate. Collaboration could be distinguished from mere cooperation, as collaboration involved working together to achieve shared goals in the cell rather than cooperating with each other to achieve their own goals in the shared cell space. It was the difference between making the most of the situation and simply getting through it. Collaborating individuals explained that they first needed to ascertain if they could trust their cellmate, as working together to achieve shared goals meant relying on each other. Interviewees described several ways of assessing their cellmate's trustworthiness. Cellmates could begin to prove themselves trustworthy by adapting their behaviour to take account of their cellmate, adhering to negotiated ground rules and practices, and displaying respect-as-consideration. Consequently, this willingness to build trust between cellmates seemed to flow naturally from and build on situations in which cellmates had successfully managed to cooperate with each other and display respect-as-consideration, fostering increased trust over time.

Just the way the time progresses. I show them they can trust me, and they show me I can trust them. That's the way... it doesn't happen the first week. Happens week after week. Actions... it is not what they say, it is the actions they do that make people trust each other. (P09)

Cellmates could also 'test' (P14) the trustworthiness of cellmates by telling them private information or examining if a cellmate respected the privacy of their possessions and private space within the cell. One man recounted telling a cellmate personal information to check if they could be trusted to keep it confidential.

You test him. [...] Just tell them something and say look, keep that to yourself. And someone on the yard will always say to you, aye, yer man or whatever. And then you know. (P14) 
In other cases, men recalled paying close attention to how they made their bed in the morning to observe whether any fresh wrinkles were visible upon their return, indicating that their private territory had been breached.

So people make their beds and know if there's any wrinkles on them or whatever. (P08)

They similarly monitored their personal possessions to determine if they had been interfered with.

You would come back and check all the things that you have to make sure they are all still there and have not been touched. (P18)

If their personal space and/or possessions had been touched, the men described feeling that their cellmate had contaminated this space/possession, often leading to conflict.

One of the major things would be photographs, family photos. That would enough for a prisoner to kill another prisoner (P13)

Indeed, it was often said that a person should not touch anything that did not belong to them when alone in the cell, without first obtaining the consent of their cellmate.

You do not touch anything in that cell that does not belong to you without asking. (P32)

Trust became rooted more firmly if, despite having the opportunity to do so, a cellmate respected the other person's space and possessions and did not interfere with them. Other ways to build trust included supporting each other if a cell became embroiled in a confrontation or ensuring that what was witnessed in the shared cell remained confidential and was not divulged to others.

If you are fighting, there are certain cellmates that will stand back and they'll not know what to do. They sort of freak out a bit. But if you are in with someone that you know, someone that you can trust, you know, if you are being tied up, if you look beside you, he is lying beside you. (P24)

Beyond making cell-sharing more survivable, trust between cellmates was important for men in shared cells to feel able to engage in introspection and self-reflection. Without trust, the presence of a cellmate hindered their ability to partake in activities, such as writing letters to family, looking at photographs or engaging in Cognitive-Behavioural Therapy (CBT) tasks:

Like the CBT work, I wouldn't really want anybody to see me doing that, because you are talking about hard things in your life. [...] About where the anxiety came from and low selfesteem and all. (P21) 
Accordingly, for those in shared cells, trust in a cellmate was required for men to be able to engage in reflective activities that supported rehabilitation and desistance.

Collaborating cellmates also used reciprocal resource-sharing as another tactic to manage the shared cell space. Cellmates had to be willing to collaborate with and to trust each other for this to be collaborative rather than exploitative. As a result, it was used less often than other tactics, like negotiation, respectful interactions and trust building. Some users of this tactic described being willing to build on previous cooperative actions to start performing more collaborative actions to the mutual benefit of both cellmates. In most cases, reciprocal resource-sharing was only used where cellmates had been cell-sharing for a while and established respectful, trustful interactions with each other which facilitated their willingness to share or because cellmates already knew each other from past periods of imprisonment or the community. These men described being willing to share resources like food, money and even drugs, to provide a more positive experience of cell-sharing and imprisonment.

So he would spend $£ 20$ on food and I would spend $£ 20$ on tobacco. So the tobacco will be there. And he doesn't have to say to me, oh, can I have a roll up? And I wouldn't have to say to him, can I take a packet of crisps and make a sandwich? (P16)

In this way, an atmosphere of shared responsibility, commensality and reciprocity was created in the cell, demonstrating a willingness to collaborate with each other to improve the experience of cell-sharing for both cellmates.

Finally, some men described being exceptionally willing to collaborate with their cellmate based on the trust that they had built up through previous displays of negotiation, respect-as-consideration, trust-building and resource-sharing. These past experiences had contributed to a willingness to nurture collegiality with their cellmate, with stories of cellmates providing peer support during times of emotional distress being heard. In these cases, the men recounted how the shared cell space could be transformed into a space where they could be vulnerable, while trusting their cellmate to support them without revealing their vulnerabilities or struggles to others.

I really broke down. So I had to lock myself in the cell and all. And [cellmate] went over, got the cell open, locked himself in the cell with me. And then tried to get my head away from things. [...] And I am thankful for that, like. Because I was ready to do something stupid (P09)

These experiences gave a distinct texture to the experience of cell-sharing, reducing the pains associated with cell-sharing and, in cases of nurturing collegiality, providing important sources of peer support to reduce distress and even self-harm.

\section{Discussion}

These findings flesh out existing research on the prison cell, which, until recently, had devoted little attention to the experience of sharing such a space, and address the calls 
for more qualitative analysis of the lived experience of cell-sharing (Molleman and van Ginneken, 2015; Turner and Knight, 2020; Muirhead et al., 2020, 2021). In doing so, it provides new insights by directly examining the difficult and often distressing realities of cell-sharing implied by studies on overcrowding (Haney, 2012; Shook, 2013). The findings indicate that, for many, cell-sharing experiences were suffused with powerlessness and claustrophobia, compounded by fears for their safety and violation of their personal space and possessions. These encroachments were experienced as assaults on their sense of self, eroding their capacity for autonomy, depriving them of dignity and instilling distress, degradation and even trauma. Only a small number spoke of benefitting from developing trusting collegial cellmate relationships, because, as suggested by van Harreveld et al. (2007) as well as Muirhead et al. (2021), cellmates could provide social and emotional peer support. Yet, for most, such relationships were unlikely to materialise, given that cell-sharing was approached with grudging acquiescence and a mindset geared more towards simple survival rather than the pursuit of supportive homosocial relationships. Such difficulties, combined with certain cellmate attributes, meant that many people were reluctant to collaborate with their cellmate and were more likely to choose to manage cell-sharing through tactics rooted in resistance or cooperation. These new insights on tactics to manage cell-sharing and cellmate relationships form the basis of a novel framework to understand how adult men manage cell-sharing and cellmate relationships, through the conceptualisation of these on a continuum of resistance, cooperation and collaboration and identifying how people's positioning on this continuum may change.

Additionally, this paper grants fresh glimpses into how masculine social norms governing behaviour in prison extend into the cell terrain. Normative masculine values of dominance, power and assertiveness impacted cellmate relationships and the tactics people used, especially tactics in the resistance domain of the continuum. Dominating the cell space or refusing to share a cell offered a way for men to demonstrate a strength of character that aligned with certain facets of hegemonic masculinity valued in prison culture (Evans and Wallace, 2008). However, the use of these tactics was not conducive to building a positive cellmate relationship. Loose comparisons may be drawn with other hypermasculine residential environments, like military barracks or boarding school dormitories, where people still manage to build positive peer relationships despite encountering similar masculine norms reflecting hegemonic masculinity (Stoudt, 2006; Green et al., 2010). Whilst there are certain unique aspects of prison cells (such as the inherent lack of choice and knowledge that peers have committed criminal offences), the similarities and differences in how men adapt and manage shared spaces in other hypermasculine environments should be investigated.

Prison cells also shape the experience of imprisonment (Herrity, 2021; Marti, 2020; Woolf, 2020). This study illustrates that cell-sharing adds another experiential layer, which is often negative. As such, prisons that routinely detain people in shared cells may not be able to meet their aim of providing safe and humane custody that promotes reduced reoffending, as that aim is jeopardised if cell-sharing causes distress or trauma. Further, cell-sharing generally does not contribute to the aim of supporting individuals in rehabilitation or desistance, as the potential anxiety caused by a cellmate's presence can 
prevent individuals from engaging in important reflective identity work (Hunter and Farrall, 2018). Prisons seeking to support individuals' desistance should not routinely use cell-sharing and instead prioritise improving physical cell conditions, including providing greater space and privacy, and giving weight to individuals' preferences as to whether they share a cell and who they share with when making decisions on cell allocation.

However, in specific, limited circumstances, cell-sharing can facilitate potential benefits through peer support. Practitioners and policymakers should be aware that accessing such benefits depends on a multitude of factors, including willingness to share and cellmate characteristics. Such factors should be built into cell allocation decision-making, expanding the current focus on risk assessments of potential violence to include more holistic considerations of how cell-sharing can support or damage wellbeing, rehabilitation and desistance. As Muirhead et al. (2020) suggest, staff require training on balancing these factors, as well as monitoring how cell-sharing arrangements progress, for example, knowing when to intervene if tactics like cell dominance are deployed or where sharing resources includes drug use that warrants moving the individuals from a shared cell to promote rehabilitation and desistance.

There are, of course, limitations to this research which must be borne in mind. As the research was conducted in Northern Ireland with adult men, its generalisability to other jurisdictions and populations may be limited. For instance, the exclusion and stigmatisation that same-sex-attracted people can experience in Northern Ireland (see Schubotz and O'Hara, 2011) may contribute to a reluctance to discuss how issues of homophobia, masculinity and sexuality influence cellmate relationships and the shared cell space in more depth. It was also a relatively small study, capturing people's views at one point in time. Future research would benefit from using a longitudinal approach and larger sample size. Additionally, most participants' cell-sharing experiences were based on cell-sharing with one other person. Cell-sharing in dormitory settings or extreme overcrowding may be different and mandate the use of different tactics to manage more acute levels of deprivation and more cellmates. Although this study shows the potential for cellmates to offer each other support, more research is needed to understand how providing such support may affect both individuals over time, as well as how staff can manage such an arrangement appropriately.

Nonetheless, despite these limitations, this study enhances our knowledge of the lived experience of cell-sharing, by exploring the detailed realities of a shared cell and conceptualising the tactics people use to manage the shared cell space and cellmate relationships as a continuum ranging from resistance to cooperation, to collaboration. This new conceptual framework furthers our understanding of how and why people respond to cellsharing in different ways. It illuminates the complexities of cell-sharing experiences and questions the ability of prisons routinely using cell-sharing to achieve their goals of holding people safely and humanely.

\section{Declaration of conflicting interests}

The authors declared no potential conflicts of interest with respect to the research, authorship, and/ or publication of this article. 


\section{Funding}

The authors disclosed receipt of the following financial support for the research, authorship, and/or publication of this article: This work was supported by a $\mathrm{PhD}$ scholarship from the former Department of Education and Learning, Northern Ireland.

\section{ORCID iDs}

Aimee Muirhead (D) https://orcid.org/0000-0001-6781-2650

Michelle Butler (iD https://orcid.org/0000-0002-6983-6215

Gavin Davidson (iD https://orcid.org/0000-0001-6003-0170

\section{Notes}

1. There are only two adult male prisons in Northern Ireland as it is a small jurisdiction with a small prison population.

2. 'Tout' was slang for a person who shares information with authorities.

\section{References}

Braun V and Clarke V (2006) Using thematic analysis in psychology. Qualitative Research in Psychology 3(2): 77-101.

Butler M, Hayes D, Devaney J, et al. (2015) Strengthening Family Relations? Review of the Families Matter Programme in Maghaberry Prison. Report. Belfast: QUB.

Butler M and Drake D (2007) Reconsidering respect: Its role in Her majesty's prison service. Howard Journal of Criminal Justice 46(2): 115-127.

Clemmer D (1958) The Prison Community. New York: Holt, Rinehart and Winston.

CJINI (2012) Report on an announced inspection of Maghaberry Prison 19-23 March 2012. Belfast: Criminal Justice Inspection Northern Ireland. Available at: http://cjini.org/ getattachment/b561aa96-c6b8-417f-9c70-a736713315e8/report.aspx (accessed 17 November 2021).

Community Justice Coalition (2018) Rapid Build Dormitory Prison Plans: An Unacceptable Pressure Cooker. Report, Community Justice Coalition, California. Available at https:// www.communityjusticecoalition.org/images/22022018_RAPID_BUILD_REPORT_FINAL_ DRAFT.pdf (accessed: 12 June 2021).

Crewe B (2011) Depth, weight and tightness: Revisiting the pains of imprisonment. Punishment \& Society 13(5): 509-529.

Crewe B, Warr J, Bennett P, et al. (2014) The emotional geography of prison life. Theoretical Criminology 18(1): 56-74.

de Viggiani N (2007) Unhealthy prisons: Exploring structural determinants of prison health. Sociology of Health \& Illness, 29(1): 115-135.

European Parliament (2017) Prison conditions in the member states: Selected European standards and best practices. Report, European Parliament, Belgium, January.

Evans T and Wallace P (2008) A prison within a prison? Men \& Masculinities 10(4): 484 507.

Grant E (2020) Ravenhall correctional centre: The master planning and architectural design of a multifaceted, people-oriented prison for Men With Complex physical and mental health needs in Victoria, Australia. Advancing Corrections 9: 146-167. 
Punishment \& Society $0(0)$

Grant E and Memmott P (2007) The case for single cells and alternative ways of viewing custodial accommodation for Australian aboriginal peoples. Flinders Journal of Law Reform 10(3): 631-646.

Green G, Emslie C, O'Neill D, et al. (2010) Exploring the ambiguities of masculinity in accounts of emotional distress in the military among young ex-servicemen. Social Science and Medicine, 71(8): 1480-1488.

Haggerty KD and Bucerius S (2020) The proliferating pains of imprisonment. Incarceration. https://doi.org/10.1177/2632666320936432

Haney C (2012) Prison effects of in the Age of mass incarceration. The Prison Journal 92(4): $1-20$.

Herrity K (2020) Hearing behind the door: The cell as a portal to prison life. In Turner J and Knight V (eds) The Prison Cell. Cham: Palgrave Macmillan, pp. 239-259.

Herrity K (2021) Hearing order in flesh and blood: Sensemaking and attunement in the Pub and the prison. In Herrity K, Schmidt BE and Warr J (eds) Sensory Penalties. Bingley: Emerald; pp. 3-18.

HMIP (2020) Report on Short Scrutiny visits to Local Prisons. Report. HM Inspectorate of Prisons, London. Available at: https://www.justiceinspectorates.gov.uk/hmiprisons/wpcontent/uploads/sites/4/2020/07/Locals-SSV-2-web-2020.pdf (accessed 12 June 2021).

Huey M and McNulty TL (2005) Institutional conditions and prison suicide: Conditional effects of deprivation and overcrowding. The Prison Journal 85(4): 490-514.

Hunter B and Farrall S (2018) Emotions, future selves and the process of desistance. British Journal of Criminology 58(2): 291-308.

Hyatt JM, Andersen SN and Chanenson SL (2020) Prison cells as a grounded embodiment of penal ideologies: A Norwegian-American comparison. In Turner J and Knight V (eds) The Prison Cell. Cham: Palgrave Macmillan, pp. 45-70.

Irwin J and Owen B (2005) Harm and the contemporary prison. In Liebling A and Maruna S (eds). The Effects of Imprisonment. UK: Willan Publishing, pp. 94-117.

Keith J (2006) Report of the Zahid Mubarek Inquiry, Volumes 1 and 2. Report. The Stationery Office: London.

Laws B and Crewe B (2016) Emotion regulation among male prisoners. Theoretical Criminology 20(4): 529-547.

Lawrence C and Andrews K (2004) The influence of perceived prison crowding on male Inmates' perception of aggressive events. Aggressive Behavior 30(4): 273-283.

Marti I (2020) "A 'home' or 'a place to Be But Not to live": Arranging the prison cell. In Turner J and Knight V (eds) The Prison Cell. Cham: Palgrave Macmillan, pp. 121-142.

Marshall T, Simpson S and Stevens A (2000) Health Care in Prisons: A Health Needs Assessment. Report, University of Birmingham, UK.

Molleman T and van Ginneken EFJC (2015) A multilevel analysis of the relationship between cell sharing, staff-prisoner relationships, and Prisoners' perceptions of prison quality. International Journal of Offender Therapy and Comparative Criminology 59(10): 1029-1046.

Moran D, Pallot J and Piacentini L (2013) Privacy in penal space: Women's imprisonment in russia. Geoforum 47: 138-146

Muirhead A (2019) Behind Closed Doors: A Study of Cell-Sharing, Wellbeing and Coping in Prison. PhD Thesis. Queen's University Belfast, UK.

Muirhead A, Butler M and Davidson G (2020) "You can't always pick your cellmate but if you can... it is a bit better": Staff and prisoner perceptions of what factors matter in cell allocation decision-making. Kriminologie-Das Online Journal 2: 159-181. 
Muirhead A, Butler M and Davidson G (2021) Behind closed doors: An exploration of cellsharing and its relationship with wellbeing. European Journal of Criminology. Epub ahead of print 21 April 2021. DOI 10.1177/1477370821996905.

Narag RE and Jones C (2020) The kubol effect: Shared governance and cell dynamics in an overcrowded prison system in the Philippines. In Turner J and Knight V (eds) The Prison Cell. Cham: Palgrave Macmillan, pp. 71-94.

Prison Reform Trust (2018) Prison: The Facts, Bromley Briefings Summer 2018. London: Prison Reform Trust

Schliehe A and Crewe B (2021) Top bunk, bottom bunk: Cellsharing in prisons. British Journal of Criminology. Epub ahead of print 14 July 2021. https://doi.org/10.1093/bjc/ azab053

Schubotz D and O'Hara M (2011) A shared future? Exclusion, stigmatization, and mental health of same-sex-attracted young people in northern Ireland. Youth \& Society, 43(2): 488-508.

Shalev S and Edgar K (2015) Deep Custody: Segregation Units and Close Supervision Centres in England and Wales, Vol. 93. London: Conquest Litho, 14.

Shook J (2013) Debunking double bunking in the correctional service of Canada: A critical qualitative account. Journal of Prisoners on Prisons 22(1), 2013: 42-63.

Silvestri A (2013) Prison Conditions in the United Kingdom. Rome: European Prison Observatory.

Stoudt BG (2006). "You're either In or you're Out": School violence, peer discipline, and the (Re)Production of hegemonic masculinity. Men and Masculinities. 8(3): 273-287

Sykes G (1958) The Society of Captives: A Study of a Maximum Security Prison. Princeton: Princeton University Press.

Toch H (1977) Living in Prison: The Ecology of Survival. New York. Free Press.

Turner J and Knight V (2020) Dissecting the cell: Embodied and everyday spaces of incarceration. In Turner J and Knight V (eds) The Prison Cell. Cham: Palgrave Macmillan, pp. 1-19.

van Harreveld F, van der Pligt J, Claassen L, et al. (2007) Inmate emotion coping and psychological and physical well-being: The use of crying over spilled milk. Criminal Justice and Behavior 34(5): 697-708.

Woolf A (2020) "I feel trapped": The role of the cell in the embodied and everyday practices of police custody. In Turner J and Knight V (eds) The Prison Cell. Cham: Palgrave Macmillan, pp. 95-118.

Aimee Muirhead is a researcher who completed her $\mathrm{PhD}$ at Queen's University Belfast before undertaking post-doctoral research at Dublin City University.

Michelle Butler is a Senior Lecturer in Criminology in the School of Social Sciences, Education and Social Work, Queen's University Belfast.

Gavin Davidson is a Professor of Social Care and Praxis Chair, in the School of Social Sciences, Education and Social Work, Queen's University Belfast. 